\title{
PLA2G7 wt Allele
}

National Cancer Institute

\section{Source}

National Cancer Institute. PLA2G7 wt Allele. NCI Thesaurus. Code C122065.

Human PLA2G7 wild-type allele is located within 6p21.2-p12 and is approximately $31 \mathrm{~kb}$ in length. This allele, which encodes platelet-activating factor acetylhydrolase protein, plays a role in the modulation of the inflammatory activity of platelet-activating factor. Mutation of the gene is associated with platelet-activating factor acetylhydrolase deficiency and increased susceptibility to asthma or atopy. 